\title{
Dual Modification of Starch Via Gamma Irradiation and Subsequent Chemical Treatment with Urea for the Development of Adhesives
}

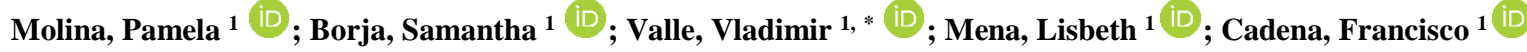 \\ ${ }^{1}$ Escuela Politécnica Nacional, Facultad de Ingeniería Química y Agroindustrial, Quito, Ecuador
}

\begin{abstract}
This research evaluates achira starch modification via gamma radiation, chemical modification and the subsequent adhesives formulation. Native starch was irradiated using a linear accelerator; the mean dose rate used was $19.5 \mathrm{kGy} / \mathrm{min}$ at ambient temperature and normal pressure. The chemical modification of irradiated starch consisted of a hydrolysis process, followed by the obtention of carbamates from the hydrolyzed starch with urea, sulphuric acid and ethanol. In order to prepare adhesives; native, modified and dual-modified starches were tested in different proportions with a polyvinyl alcohol (PVA) solution. Fourier Transformed Infrared Spectroscopy (FTIR) analysis showed all modified starches had a lower intensity in the band between 1100 and $900 \mathrm{~cm}^{-1}$ due to the damage in the glycosidic bonds. Only single modified starches evidenced a characteristic band at $1715 \mathrm{~cm}^{-1}$, which corresponds to the group carbonyl $(\mathrm{C}=\mathrm{O})$ of carbamates. The viscosity of native starch adhesives increased with the starch-PVA, unlike, single and dual-modified starch adhesives. The shear bond strength did not change significantly in the adhesives formulated either with starch modified by urea or electron beam irradiation. The combination of hydrolysis with gamma radiation caused strong damage in the starch structure. However, despite the molecular destruction of polysaccharide, the adhesion capacity for non-irradiated starches is similar in all cases.
\end{abstract}

Keywords: adhesives, modification, starch, irradiation, urea.

\section{Doble Modificación de Almidón, Vía Irradiación Gamma y Posterior Tratamiento Químico con Urea, para el Desarrollo de Adhesivos}

\begin{abstract}
Resumen: Esta investigación evalúa la modificación de almidón de achira vía radiación gamma, y subsecuente modificación química para la formulación de adhesivos. El almidón nativo fue irradiado empleando un acelerador lineal con una tasa media de $19.5 \mathrm{kGy} / \mathrm{min}$ a temperatura ambiente y presión atmosférica. La modificación química de almidón irradiado consistió en un proceso de hidrólisis, seguido de la obtención de carbamatos a partir del almidón hidrolizado usando urea, ácido sulfúrico y etanol. Para la elaboración de adhesivos, se probó almidón nativo, almidón modificado y doblemente modificado en diferentes proporciones con una solución de polivinil alcohol (PVA). El análisis por Espectroscopía Infrarroja por Transformadas de Fourier (FTIR) mostró que los almidones modificados tuvieron una menor intensidad en la banda entre 1100 y $900 \mathrm{~cm}^{-1}$ debido al daño en los enlaces glucosídicos. Solo los almidones con modificación simple evidenciaron la banda característica a $1715 \mathrm{~cm}^{-1}$, correspondiente al grupo carbonilo $(\mathrm{C}=\mathrm{O})$ del carbamato. La viscosidad de los adhesivos de almidón nativo aumentó con la relación de almidón-PVA, al contrario de los adhesivos con almidón simple y doblemente modificado. Los resultados de la resistencia al cizallamiento indicaron que la modificación del almidón con urea o con irradiación no afectó significativamente esta propiedad. La combinación de hidrólisis con el ataque del haz de electrones causó un fuerte daño en la estructura del almidón. Sin embargo, la capacidad de adhesión de los almidones no irradiados es similar en todos los casos.
\end{abstract}

Palabras clave: adhesivos, modificación, almidón, irradiación, urea.

\section{INTRODUCTION}

Synthetic adhesives derivate from petroleum resources are used in countless applications, due to their versatile mechanical, physical and chemical properties (Dinte and Sylvester, 2018). As a result of the excessive dependence on fossil-raw-materials and environmental concern; greater efforts have focused on the development of bio-based

*vladimir.valle@epn.edu.ec

Recibido: 28/03/2020

Aceptado: 05/06/2020

Publicado: 31/08/2020

10.33333/rp.vol46n1.04

CC BY 4.0 
alternatives than traditional adhesives (Heinrich, 2019; Richter, et al., 2018).

Polyvinyl alcohol (PVA) is a thermoplastic synthetic biodegradable polymer. Its physicochemical characteristics and low cost had expanded the use of PVA in food, packaging, textile, manufacturing, paper and paint industries as well as in medical and pharmaceutical applications (Demerlis and Schoneker, 2003; Limpan, et al, 2012). Due to its nontoxic nature and water solubility; PVA becomes a potential alternative to develop bio adhesives (Maria, et al., 2008).

Over the last decades numerous bio-based adhesives have developed with a number of different renewable raw materials such as proteins, polysaccharides, polyphenols and lipids (Ferdosian, et al., 2017; Heinrich, 2019; Pizzi and Mittal, 2017). Starch, a naturally occurring hydrophilic polysaccharide, is formed by amylose and amylopectin; though, the ratio of these components vary depending on edaphoclimatic factors (Ferdosian et al., 2017; Zhang et al., 2015). Starch is currently used in adhesives, carpets, textiles, paper and water treatments as well as in medical applications as excipient, absorbent, and encapsulant (Kavlani, Sharma and Lalit, 2012; Menzel et al., 2017).

From the perspective of adhesive formulation, native starch shows some limitations in terms of bonding capacity, thermal decomposition and storage stability. Therefore, the modification of starch microstructure is highly required. Particularly, modified starches increase the solids content leading to shorter drying times and higher bond strength (Qiao et al., 2017). Furthermore, it has been reported that some modification procedures reduce retrogradation phenomena (Ashogbon, 2018).

Physical, chemical, enzymatic, and genetic modifications are commonly used for starch derivatization (Gadhave, et al., 2017; Kaur, et al., 2012). Nevertheless, chemical modification is one of the most versatile route due to starch molecule separation into small units and potential reactivity of hydroxyl groups (Bhattacharyya, et al., 2015; Kavlani et al., 2012). Furthermore, chemical derivatization has been combined with other modification methods such as extrusion and microwave to enhance starch properties (Kaur et al., 2012; Kavlani et al., 2012).

Urea derivatization, a well-known chemical modification method, has widely been used to carbamate formation (Sun, $\mathrm{Gu}$, Tan, Zhang, and Huo, 2018). Moreover, starch carbamate is produced as result of the reaction of the starch with urea in solid state at high temperatures. In this context, it has been proposed that starch carbamate improve bonding capacity of adhesives (Menzel et al., 2017; Tomasik, 2003).

Additionally, several investigations have focused on starch modification through emerging technologies like high hydrostatic pressure, ultrasound, electrical pulses and radiation. These technologies are environmentally friendly and less polluting, than traditional techniques. Specifically, radiation has shown significant benefits in chemical modification of starches (Ashogbon, 2018). Low levels of $\gamma$ radiation promote the formation of free radicals which in turn generate not only solubility increase but also reduction of viscosity and swelling power (Atrous et al., 2015; Sokhey and Hanna, 1993). However, doses greater than $100 \mathrm{kGy}$ have shown to damage the structure of the polysaccharide (Sokhey and Hanna, 1993).

In recent years, several starches namely, wheat, corn, rice, cassava and potato have been studied in eco-adhesives elaboration (Gadhave et al., 2017; Turunen et al., 2003). However, limited number of investigations focused on nontraditional Andean starches have been reported in specialized literature. In order to contribute with alternatives to reduce non-renewable resources dependence, the aim of this research is to study single chemical modification and dual modification (gamma irradiation and chemical modification with urea) of achira (Canna edulis) starch to develop bio-based adhesives.

\section{METHODOLOGY}

\subsection{Materials}

PVA (88\% hydrolyzed) was procured from Sekisui Chemical Co., Ltd. (Japan). Food grade achira starch (23,8 \% amylose) was purchased from Colinas Verdes Foundation (Ecuador). All reagents (urea, sulfuric acid, ethanol, glycerol, sodium carbonate and hydrochloric acid) used were of analytical grade. Plywood veneers were obtained from Endesa-Botrosa (Ecuador) and cut into strips (100 mm x 15mm). The thickness of veneers was $3 \mathrm{~mm}$.

\subsection{Methods}

The starch used in this research was modified in two stages:

\section{-Electron Beam Processing}

Native achira starch was dried at $40{ }^{\circ} \mathrm{C}$ for $24 \mathrm{~h}$ and packed up in polyethylene bags (thickness of $49 \mathrm{~mm}$, area of $70 \mathrm{~mm} \times 80$ $\mathrm{mm})$. Then it was treated with a scanned electron beam using a linear accelerator ELU-6U with 6,8 MeV mean energy and mean dose rate of $19,5 \mathrm{kGy} / \mathrm{min}$ at ambient temperature and normal pressure. The irradiation dose $(50 \mathrm{kGy})$ was checked using cellulose triacetate film.

\section{-Chemical modification of starch}

For the production of starch carbamate, irradiated starch was initially hydrolyzed, following the methodology proposed by Mostafa, (2003). Starch and $1 \mathrm{~N} \mathrm{HCl} \mathrm{(1:5)} \mathrm{were} \mathrm{mixed} \mathrm{at} 50$ ${ }^{\circ} \mathrm{C}$ for $60 \mathrm{~min}$ and neutralized with $14 \%$ sodium carbonate solution. Ethanol was added to precipitate the hydrolyzed starch. The product was dried in an oven at $60^{\circ} \mathrm{C}$ for $2 \mathrm{~h}$.

Starch carbamate was prepared according the method proposed by Menzel et al., (2017). Urea (20\% of the amount of starch), $1 \mathrm{~mL}$ sulfuric acid and $15 \mathrm{~mL}$ ethanol were blended with hydrolyzed starch. The mix was heated in an oven at 100 ${ }^{\circ} \mathrm{C}$ for $3 \mathrm{~h}$. The product was washed in ethanol:water (70:30) and centrifuged at $1000 \mathrm{~g}$ for $10 \mathrm{~min}$. 


\section{Characterization of modified starch:}

\section{- FTIR}

Infrared analysis of starch was recorded on a spectrometer Perkin Elmer, model Spectrum One. Data were collected over 16 scans with a resolution of $4 \mathrm{~cm}^{-1}$ in a range of wavenumber from 4000 to $650 \mathrm{~cm}^{-1}$.

\section{-Water binding capacity}

Water binding capacity was measured according to Yousif, et al., (2012). A gram of starch and $15 \mathrm{~mL}$ distilled water were centrifuged at $1250 \mathrm{~g}$ for $20 \mathrm{~min}$. The supernatant was discarded, and the weight of water bound by the dried sample was measured.

\section{Preparation of adhesives}

Water, glycerol, ethanol, and mineral oil were stirred for three minutes at $200 \mathrm{rpm}$. PVA was added to unheated solution in ratio 1:5 under continuous agitation and the suspension was heated at $85{ }^{\circ} \mathrm{C}$ and stirred for 30 minutes at $75 \mathrm{rpm}$. The solution composition is presented in Table 1 .

\begin{tabular}{cc}
\multicolumn{2}{c}{ Table 1. Composition of PVA solution } \\
\hline Component & $\begin{array}{c}\text { Percentage on the PVA } \\
\text { solution }(\%)\end{array}$ \\
\hline PVA & 20,00 \\
Water & 68,00 \\
Glycerol & 10,00 \\
Ethanol & 20,00 \\
Mineral oil & 2,00 \\
\hline
\end{tabular}

Once the PVA solution was obtained; starch, 0,2 $\mathrm{g}$ of sodium benzoate and five grams of water for each gram of starch were added to the solution with continuous stirring. The final composition of each adhesive, with PVA composition constant, is described in Table 2.

Table 2. Starch-PVA adhesives composition

\begin{tabular}{ccc}
\hline Sample & Starch & $\begin{array}{c}\text { Composition } \\
\text { (g starch/g PVA solution) }\end{array}$ \\
\hline M1 & Native & 0,06 \\
M2 & & 0,17 \\
M3 & & 0,28 \\
M4 & Modified & 0,06 \\
M5 & & 0,17 \\
M6 & & 0,28 \\
M7 & Dual-modified & 0,06 \\
M8 & & 0,17 \\
M9 & & 0,28 \\
\hline
\end{tabular}

\section{Adhesive characterization}

\section{-Shear bond strength test}

Shear bond strength was performed according to the methodology proposed by Kim and Netravali, (2013) using a universal testing machine Instron, model 3365. Plywood strips were sanded with a 600 grit-sandpaper. Two plywood strips were settled as shown in Figure 1; adhesive was applied on a $15 \mathrm{~mm} \times 15 \mathrm{~mm}$ area at the end of the strips with a multiple clearance square applicator (5 mils). The crosshead speed was $1 \mathrm{~mm} / \mathrm{min}$.
Shear bond strength $\tau$ was calculated by equation (1), where $P m$ is the maximum load at break and $A$ is the joint overlap area. Five specimens were tested for each sample.

$$
\tau=\frac{P_{m}}{A}
$$

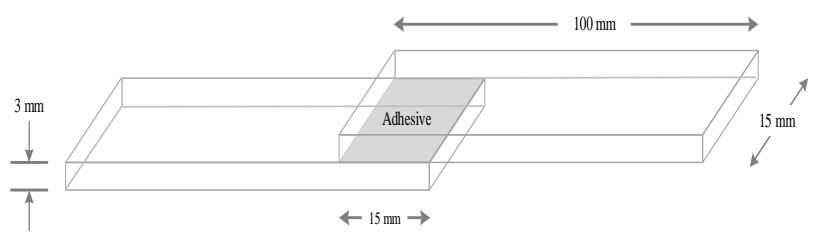

Figure 1. Schematic of the adhesive shear bond strength test- specimen

-Determination of apparent viscosity

Apparent viscosity of adhesives was determined with rotational viscometer Fungilab, model EVO Expert at $4 \mathrm{rpm}$ using spindle number TL9. The viscosity was measured in triplicate at $25 \pm 1{ }^{\circ} \mathrm{C}$.

\section{RESULTS AND DISCUSSION}

\subsection{FTIR evaluation}

FTIR results are presented in Figure 2. On the whole, infrared spectrums showed a broad band in the range of $3600-3000 \mathrm{~cm}^{-1}$ corresponding to $\mathrm{OH}$ stretching vibration and $\mathrm{CH}$ stretching functional groups (Kizil, et al., 2002). A band at $3440 \mathrm{~cm}^{-1}$, ascribed to $\mathrm{NH}$ asymmetric stretching of carbamate group, was identified in modified starch spectrum (Menzel et al., 2017). Moreover, the band at $1715 \mathrm{~cm}^{-1}$ corresponding to carbonyl $(\mathrm{C}=\mathrm{O})$ stretching vibrations ratified starch carbamate formation. (Siemion, et al., 2004).

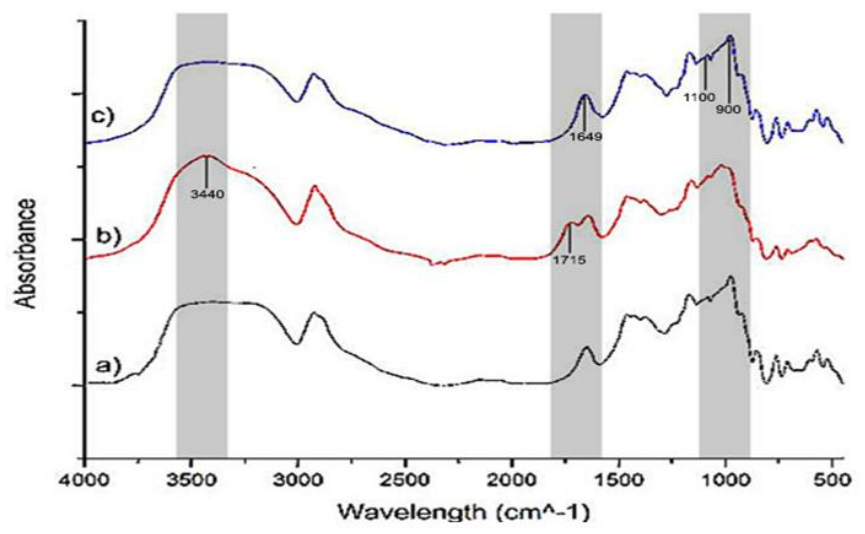

Figure 2. FTIR spectrum of a) native b) modified and c) dual-modified starches

Dual-modified starch did not present $\mathrm{NH}$ and $\mathrm{C}=\mathrm{O}$ bands, suggesting electron beam action inhibited the formation of starch carbamate. This behavior is probably associated to the higher degradation caused by radiation in comparison with the chemical route (Wu and Song, 2006). According to Wang, et al., (2017) the absence of $\mathrm{C}=\mathrm{O}$ band could be a result of high degree of deterioration of active sites in starch.

Furthermore, the variation of the band intensity located at $1649 \mathrm{~cm}^{-1}$ was observed. This corresponds to the water 
absorbed in the amorphous starch region (Kizil et al., 2002). As a result, greater amount of water could be absorbed (Menzel et al., 2017). The destruction of the crystalline structure of the starch by the electron beam is greater than the action caused by chemical substances, since the radiation achieves a greater penetration into polysaccharide structure (Wu and Song, 2006). Otherwise, Warren, et al., (2015), reported that modification treatments decrease intensity of the bands associated with $\mathrm{C}-\mathrm{O}$ and $\mathrm{C}-\mathrm{C}$ stretching vibrations and $\mathrm{C}-\mathrm{O}-\mathrm{H}$ bending from glycosidic bonds.

\subsection{Water binding capacity}

Table 3 shows the binding capacity of native and modified starches. It is noticed that global modification treatment affected hydrogen bonds. The results suggest that high polarity of starch carbamates had an important influence in water binding capacity (Darmanin and Guittard, 2015). In addition, hydrogen bond formation occurs preferentially between starch carbamate and nearby starch molecules (Menzel et al., 2017; Wilpiszewska and Spychaj, 2007).

Table 3. Water binding capacity of native and modified starches

\begin{tabular}{cc}
\hline Sample & $\begin{array}{c}\text { Water binding } \\
\text { capacity }(\mathbf{g} / \mathbf{g})\end{array}$ \\
\hline Native starch & $0,91 \pm 0,02$ \\
Modified starch & $1,26 \pm 0,13$ \\
Dual-modified starch & $1,18 \pm 0,09$ \\
\hline
\end{tabular}

On the other hand, gamma irradiation doses contribute to the acidity and solubility in water as well as to the decrease of viscosity in starches. The enhanced solubility was produced due to the division of the chain under irradiation and consequently decrease of hydrogen bonds between chains and the formation of smaller molecules such as sugars and dextrins (Mathias, et al., 2016). Despite this, the reason for the lower value $(1,18 \pm 0,09)$ for irradiated starches, in comparison with chemically modified starches $(1,26 \pm 0,13)$, is due to the absence of $\mathrm{C}=\mathrm{O}$ carbamate group.

Starch molecules experienced significant changes in their structure due to the degradation phenomenon induced by ionizing radiation processing (Liu, Ma, Xue and Shi, 2012). According to Bhat and Karim, (2009), the application of ionizing radiation generates free radicals which are able to promote molecular changes and fragmentation of starch. This property has been suggested to be one of the main mechanisms underlying physicochemical changes in starch, like reduction of viscosity and high-water solubility.

\subsection{Characterization of adhesives}

\section{-Shear bond strength test}

Figure 3 shows shear bond strength results. Overall, no significant differences among samples were observed. However, it is noticed that shear bond strength of dual modified starch (M7, M8 and M9) was slightly lower than the other samples. This characteristic is related not only to the number of polar functional groups (Mathias et al., 2016) but also with the molecular weight decrease due to radiation process (Kamal et al., 2007). Besides, the high polarity of $\mathrm{C}=\mathrm{O}$ groups allowed to improve adhesion on lignocellulosic substrates (Mathias et al., 2016; Neuman, 2004).

Imam et al., (1999) reported that increase of starch concentration leads to a better interaction between starch and cellulose derivatives of the wood. However, this trend was not identified in the presented study which is possibly ascribed to non-controlled adhesive thickness applied in plywood (Mathias et al., 2016). Indeed, viscosity variation of tested samples leads to heterogeneous thickness applied and consequently changes in shear bond strength.

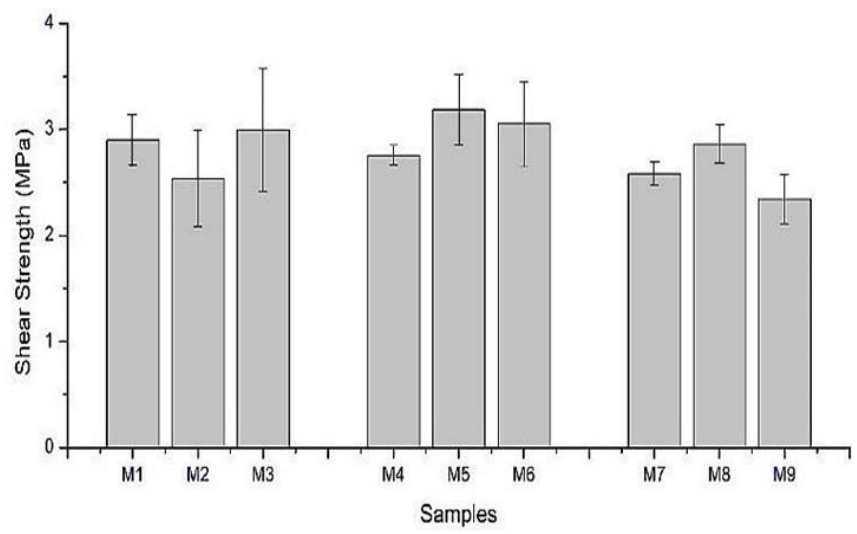

Figure 3. Shear bond strength of starch-PVA adhesives

\section{-Apparent viscosity}

Viscosity is a determining factor in adhesives production, since it allows to control its wettability on substrates. Adhesives with high viscosity cannot spread appropriately on adherent surface, and consequently have a low bond strength. On the other hand, adhesives with low viscosity flow easily, spill from the surface, and do not achieve good adhesion (Wang et al., 2017).

Results of apparent viscosity are presented in Figure 4. Noticed that the viscosity of native starch adhesives exhibits an increasing trend as a function of the increment of starchPVA ratio.

The gelatinization process is associated to the starch concentration due to the leaching of amylose that occurs when the starch granules are heated, swell and break their structure (Menzel et al., 2017). The viscosity increases due to the greater interaction between the hydrogen bonds of the polysaccharide molecules with those of water (Lewicka, Siemion and Kurcok, 2015).

Contrary to the results of native starch samples, the viscosity of the modified and dual-modified starch adhesives decreases as the starch-PVA ratio increases. It should be noted that, in both cases, the starch used in the adhesives was subjected to a process of depolymerization by acid attack, which causes the polysaccharide chains to break (Ashogbon and Akintayo, 2014). Moreover, with the dual-modified starch, there was a previous process of depolymerization by the attack of the electron beam, which increased this degradation (Lee et al., 2006). 


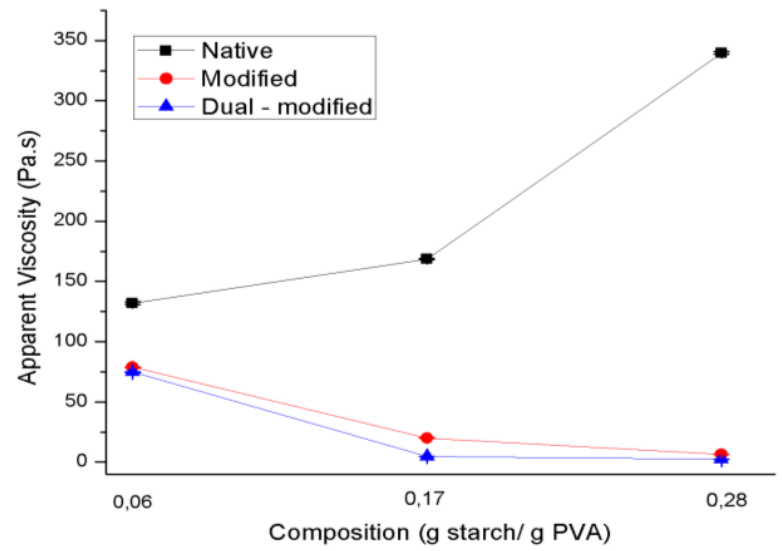

Figure 4. Apparent viscosity of starch-PVA adhesives

Kamal et al., (2007) points out that starches exposed to modifications by chain decomposition exhibit low viscosities due to the breakdown of glycosidic bonds between glucose molecules. Once these bonds are cut, they cannot be joined again with the same force and the viscosity of the modified starches is always lower than that of the native ones (Kaur et al., 2012).

\section{CONCLUSIONS}

This research studied two methods of starch modification and their effect on the shear bond strength and apparent viscosity. The single modified starch showed two characteristic bands at $3440 \mathrm{~cm}^{-1}$ and $1715 \mathrm{~cm}^{-1}$ corresponding to $\mathrm{NH}$ stretching of starch carbamate and $\mathrm{C}=\mathrm{O}$ stretching vibrations, respectively. However, the presence of either $\mathrm{NH}$ or $\mathrm{C}=\mathrm{O}$ bands were not observed in dual-modified starch. Furthermore, the combination of electron beam with the hydrolysis of chemical treatment, in dual modification, produced strong degradation in starch structure.

The viscosity of the native starch adhesives showed a direct relationship with the starch concentration. However, the opposite behaviour was observed in both modified and dualmodified starch adhesives. This particularity was attributed to the inability to form polymer networks between starch and water, due to excess degradation in the structure of the polysaccharide. Finally, the improvement in shear resistance was related to the presence $\mathrm{C}=\mathrm{O}$ group of the starch carbamate. Nevertheless, similar results were observed with starches without this group in their structure.

Future prospective would be focused on testing the effect of microstructure of other lignocellulosic substrates (oak, guayacan, ebony, eucalyptus, teak, pine, etc.) on adhesion mechanism. Further characterization in terms of storage stability, and biodegradability will also be necessary.

\section{ACKNOWLEDGMENTS}

The authors gratefully acknowledge the financial support provided by Escuela Politécnica Nacional, for the development of the project PIJ-16-11 "Desarrollo de adhesivos y encolantes formulados a partir de almidón modificado y polivinil alcohol".

\section{REFERENCES}

Ashogbon, A. (2018). Current Research Addressing Physical Modification of Starch from Various Botanical Sources. Global Nutrition and Dietetics, 1(1), 1-7. Retrieved from https://scientonline.org/openaccess/current-research-addressing-physicalmodification-of-starch-from-various-botanicalsources.pdf

Ashogbon, A., and Akintayo, E. (2014). Recent trend in the physical and chemical modification of starches from different botanical sources: A review. Starch/Staerke, 66(1-2), 41-57. doi:10.1002/star.201300106

Atrous, H., Benbettaieb, N., Hosni, F., Danthine, S., Blecker, C., Attia, H., and Ghorbel, D. (2015). Effect of $\gamma$ radiation on free radicals formation, structural changes and functional properties of wheat starch. International Journal of Biological Macromolecules, 80, 64-76. doi:10.1016/j.ijbiomac.2015.06.014

Bhat, R., and Karim, A. A. (2009). Impact of Radiation Processing on Starch. Comprehensive Reviews in Food Science and Food Safety, 8, 1-20. doi:10.1111/j.15414337.2008.00066.x

Bhattacharyya, D., Spychaj, S., Spychaj, T., Wilpiszewska, K., and Fakirov, S. (2015). Starch-Urethane Polymers: Physicochemical Aspects, Properties, Application. Handbook of Engineering Biopolymers, 155-191. doi:10.3139/9783446442504.005

Darmanin, T., and Guittard, F. (2015). Highly Polar Linkers ( Urea , Carbamate , Thiocarbamate ) for Superoleophobic / Superhydrophobic or Oleophobic / Hydrophilic Properties. Advanced Material Interfaces, 40(4), 1-7. doi:10.1002/admi.201500081

Demerlis, C. C., and Schoneker, D. R. (2003). Review of the oral toxicity of polyvinyl alcohol (PVA). Food and Chemical Toxicology, 41(3), 319-326. doi:10.1016/S0278-6915(02)00258-2

Dinte, E., and Sylvester, B. (2018). Adhesives: Applications and Recent Advances. Applied Adhesive Bonding in Science and Technology. doi:10.5772/intechopen.71854

Ferdosian, F., Pan, Z., Gao, G., and Zhao, B. (2017). Bio-based adhesives and evaluation for wood composites application. Polymers, 9(2), 10-29. doi:10.3390/polym9020070

Gadhave, R., Mahanwar, P., and Gadekar, P. (2017). StarchBased Adhesives for Wood/Wood Composite Bonding: Review. Open Journal of Polymer Chemistry, 07(02), 19-32. doi:10.4236/ojpchem.2017.72002

Heinrich, L. (2019). Future opportunities for bio-based adhesives-advantages beyond renewability. Green Chemistry, 21(8), 1866-1888. doi:10.1039/c8gc03746a 
Imam, S., Mao, L., Diego, S., Chen, L., and Greene, R. (1999). Wood Adhesive from Crosslinked Poly(Vinyl Alcohol) and Partially Gelatinized Starch Preparation and Properties. Starch - Stärke, 51, 225-229. doi:10.1002/(SICI)1521-

379X(199906)51:6<225::AID-STAR225>3.0.CO;2-F

Kamal, H., Sabry, G., Lotfy, S., Abdallah, N., Ulanski, P., Rosiak, J., and Hegazy, E. (2007). Controlling of degradation effects in radiation processing of starch. Journal of Macromolecular Science, Part A: Pure and Applied Chemistry, 44(8), 865-875. doi:10.1080/10601320701407961

Kaur, B., Ariffin, F., Bhat, R., and Karim, A. (2012). Progress in starch modification in the last decade. Food Hydrocolloids, $\quad$ 26(2), 398-404. doi:10.1016/j.foodhyd.2011.02.016

Kavlani, N., Sharma, V., and Lalit, S. (2012). Various techniques for modification of starch and applications of its derivatives. International Research Journal of Pharmacy, 3(5), 25-31. doi:10.7897/2230-8407

Kim, J., and Netravali, A. (2013). Performance of proteinbased wood bioadhesives and development of smallscale test method for characterizing properties of adhesive-bonded wood specimens. Journal of Adhesion Science and Technology, 27(18-19), 20832093. doi:10.1080/01694243.2012.697658

Kizil, R., Irudayaraj, J., and Seetharaman, K. (2002). Characterization of irradiated starches by using FTRaman and FTIR spectroscopy. Journal of Agricultural and Food Chemistry, 50(14), 3912-3918. doi:10.1021/jf011652p

Lee, Y., Kim, S., Lim, S., Han, S., Kim, H., and Kang, I. (2006). Physicochemical Properties of Gamma Irradiated Corn Starch. Food Science and Nutrition, 11(1), 146-154. doi:10.3746/jfn.2006.11.2.146

Lewicka, K., Siemion, P., and Kurcok, P. (2015). Chemical modifications of starch: Microwave effect. International Journal of Polymer Science, 2015, 1-10. doi:10.1155/2015/867697

Limpan, N., Prodpran, T., Benjakul, S., and Prasarpran, S. (2012). Influences of degree of hydrolysis and molecular weight of poly(vinyl alcohol) (PVA) on properties of fish myofibrillar protein/PVA blend films. Food Hydrocolloids, 29(1), 226-233. doi:10.1016/j.foodhyd.2012.03.007

Liu, T., Ma, Y., Xue, S., and Shi, J. (2012). Modifications of structure and physicochemical properties of maize starch by $\gamma$-irradiation treatments. LWT - Food Science and Technology, 46(1), 156-163. doi:10.1016/j.lwt.2011.10.012

Maria, T., de Carvalho, R, Sobral, P., Habitante, A., and Solorza, J. (2008). The effect of the degree of hydrolysis of the PVA and the plasticizer concentration on the color, opacity, and thermal and mechanical properties of films based on PVA and gelatin blends. Journal of Food Engineering, 87(2), 191-199. doi:10.1016/j.jfoodeng.2007.11.026

Mathias, J., Grédiac, M., y Michaud, P. (2016). Bio-based adhesives. In Volodymyr, I. (Ed.), Biopolymers and Biotech Admixtures for Eco-Efficient Construction Materials (pp. 369-385). Waltham, United States: Woodhead Publishing

Menzel, C., Seisenbaeva, G., Agback, P., Gällstedt, M., Boldizar, A., and Koch, K. (2017). Wheat starch carbamate: Production, molecular characterization, and film forming properties. Carbohydrate Polymers, 172(2), 365-373. doi:10.1016/j.carbpol.2017.05.053

Mostafa, K. (2003). Evaluation of nitrogen containing starch and hydrolyzed starch derivatives as a size base materials for cotton yarns. Carbohydrate Polymers, 51(1), 63-68. doi:10.1016/S0144-8617(02)00106-6

Neuman, R. (2004). Carbonyl Compounds: Ketones , Aldehydes , Carboxylic Acids. In Neuman, R.(Ed.), Organic Chemistry (pp.3-33). California, United States: University of California Riverside.

Pizzi, A., and Mittal, K. (2017). Handbook of Adhesive Technology (3th. ed.). New York, United States: Taylor y Francis Group

Qiao, Z., Lv, S., Gu, J., Tan, H., Shi, J., and Zhang, Y. (2017). Influence of acid hydrolysis on properties of maize starch adhesive. Pigment and Resin Technology, 46(2), 148-155. doi:10.1108/PRT-10-2015-0105

Richter, K., Grunwald, I., y Byern, J. (2018). Bioadhesives (1th. ed.). Bremen, Germany: Springer International Publishing AG

Siemion, P., Jabłońska, J., Kapuśniak, J., and Kozioł, J. (2004). Solid state reactions of potato starch with urea and biuret. Journal of Polymers and the Environment, 12(4), 247-255. doi:10.1007/s10924-004-8152-2

Sokhey, A., and Hanna, M. (1993). Properties of Irradiated Starches, Food Structure, 12(4), 397-410. doi:10.1.1.820.4733

Sun, Y., Gu, J., Tan, H., Zhang, Y., and Huo, P. (2018). Physicochemical properties of starch adhesives enhanced by esterification modification with dodecenyl succinic anhydride. International Journal of Biological Macromolecules, 112, 1257-1263. doi:10.1016/j.ijbiomac.2018.01.222

Tomasik, P. (2003). Nonnutritional Apliccations of Saccharides and Polysaccharides. In P. Tomasik (Ed.), Chemical and functional properties of food saccharides (pp. 315-324). Boca Ratón, United States: Taylor and Francis Group. 
Turunen, M., Alvila, L., Pakkanen, T., and Rainio, J. (2003). Modification of phenol-formaldehyde resol resins by lignin, starch, and urea. Journal of Applied Polymer Science, 88(2), 582-588. doi:10.1002/app.11776

Wang, Y., Xiong, H., Wang, Z., Zia, D., and Chen, L. (2017). Effects of different durations of acid hydrolysis on the properties of starch-based wood adhesive. International Journal of Biological Macromolecules, 103, 819-828. doi:10.1016/j.ijbiomac.2017.05.102

Warren, F., Gidley, M., and Flanagan, B. (2015). Infrared spectroscopy as a tool to characterise starch ordered structure- a joint FTIR-ATR, NMR, XRD and DSC study. Carbohydrate Polymers. 139, 35-42. doi:10.1016/j.carbpol.2015.11.066

Wilpiszewska, K., and Spychaj, T. (2007). Chemical modification of starch with hexamethylene diisocyanate derivatives. Carbohydrate Polymers, 70, 334-340. doi:10.1016/j.carbpol.2007.04.023

Wu, Z., and Song, X. (2006). Carboxymethylation of $\gamma$ irradiated starch. Journal of Applied Polymer Science, 101(4), 2210-2215. doi:10.1002/app.23479

Yousif, E., Gadallah, M., and Sorour, A. (2012). Physicochemical and rheological properties of modified corn starches and its effect on noodle quality. Annals of Agricultural Sciences, 57(1), 19-27. doi:10.1016/j.aoas.2012.03.008

Zhang, Y., Ding, L., Gu, J., Tan, H., and Zhu, L. (2015). Preparation and properties of a starch-based wood adhesive with high bonding strength and water resistance. Carbohydrate Polymers, 115, 32-57. doi:10.1016/j.carbpol.2014.08.063

\section{BIOGRAFÍAS}

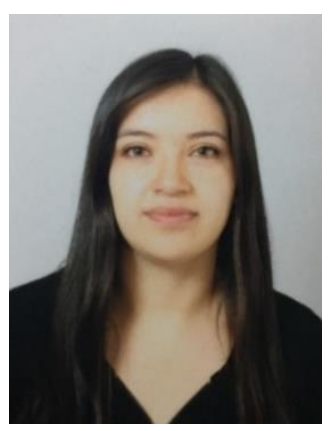

Pamela Molina, received her degree in Agro-industrial Engineering from Escuela Politécnica Nacional, Ecuador. She is a student of the Sustainable Systems Engineering Master program at the Albert-LudwigsUniversität Freiburg, Germany. She has participated in research projects related to starches for film and adhesive applications. Her research interests are bio-based polymers and bio-inspired materials. ORCID: https://orcid.org/0000-0001-6829-9190

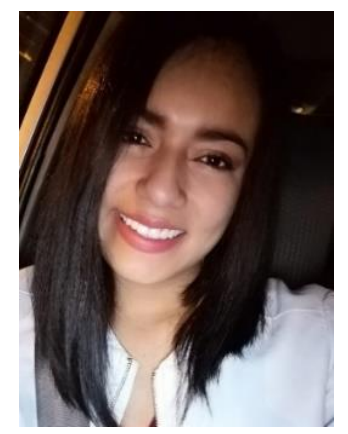

Samantha Borja, Born on 29 October 1996 in Quito, Ecuador. She has previously participated as speaker at CONEIQ 2018, held at the San Francisco University in Quito, with the subject: "Degradation of azoic dye Direct Blue BRL through two absorption techniques:Fenton and Persulfate ions. She is currently developing her degree project on "Development of adhesives from polyvinyl alcohol and achira (Canna Edulis) modified starch ", to obtain the degree of Chemical Engineer at the National Polytechnic School.

ORCID: https://orcid.org/0000-0003-1837-9517

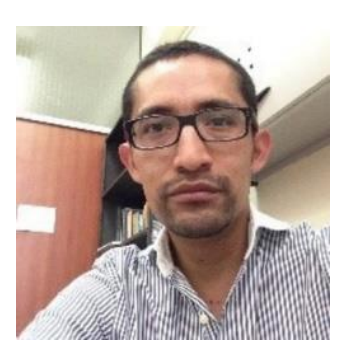

Vladimir Valle, received his MSc in Advanced Materials Science and Engineering from Universitat Politècnica de Catalunya, Barcelona, Spain and Luleå University of Technology, Luleå, Sweden. He is currently a researcher at Centro de Investigaciones Aplicadas a Polímeros-Escuela Politécnica Nacional, Quito, Ecuador. His research fields are material processing, bio-based polymers, and greater durability composites based on agroindustry wastes.

ORCID: https://orcid.org/0000-0003-3344-8111

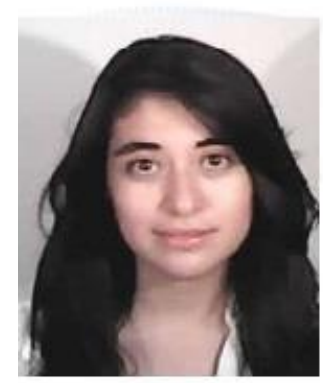

Lisbeth Mena, She has been awarded with a scholarship under the Emerging Leaders in the Americas Program (ELAP) by the Canadian Bureau for International Education (CBIE) (2016- 2017). Through it, she worked as an exchange research student in the Catalytic Ozonation Laboratory of the Chemical Engineering Faculty at the University of Saskatchewan, (Saskatoon-Canada). She developed research on Advanced Oxidation Processes (POA's) for wastewater treatment, under the supervision of the professor Jafar Soltan. She has contributed for poster presentations at the 3rd Iberoamerican Conference on Advanced Oxidation Technologies (III CIPOA) and at the 67th Canadian Chemical Engineering Conference. Chemical Engineer from the National Polytechnic School (2018). She has played roles within the pharmaceutical industry, teaching and research scopes.

ORCID: https://orcid.org/0000-0002-8851-4465 


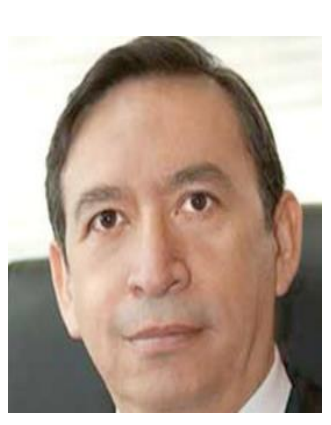

Francisco Cadena, Chemical Engineer, Faculty of Chemical Engineering, National Polytechnic School (EPN). Scientific internship Materials Department, Lausanne Federal Polytechnic School (EPFL), Switzerland. Doctorate $(\mathrm{PhD})$ Polytechnic University of Catalonia (UPC). Postdoctoral University of the Basque Country. President of the Council for Evaluation, Accreditation and Quality Assurance (CEAACES) Ecuador. Member of the Council of Higher Education of Ecuador (CES). Advisor to the Ministry of Education of Ecuador. External pair in the evaluation University of Havana. Visiting Professor University of the Basque Country. Guest Professor University of Holguín. Guest Professor University of Havana. Member of the Technical Committee Latincorr NACE.

ORCID: https://orcid.org/0000-0003-4510-1844 